\title{
Hepatitis C Associated B-cell Non-Hodgkin Lymphoma: Clinical Features and the Role of Antiviral Therapy
}

\author{
Syed Tasleem ${ }^{1}$ and Gagan K Sood*1,2 \\ ${ }^{1}$ Department of Surgery, St. Luke's Center for Liver Disease, Baylor College of Medicine, Houston, Texas, USA; ${ }^{2}$ Department of \\ Gastroenterology and Hepatology, Baylor College of Medicine, Houston, Texas, USA
}

\begin{abstract}
The link between chronic hepatitis $\mathrm{C}$ virus (HCV) infection and a subset of B-cell non-Hodgkin lymphomas (B-NHL) is strongly supported by epidemiological studies. Evidence demonstrating complete regression of lymphoma after antiviral treatments suggests possible chronic antigenic stimulation for the origin of $\mathrm{B}-\mathrm{NHL}$ and provides evidence for a virus-mediated lymphomagenesis. B-NHL is a heterogeneous group of lymphomas with varied clinical presentation and may be indolent or aggressive. The optimal management of HCV related $\mathrm{B}-\mathrm{NHL}$ is not clear. Antiviral treatment may be sufficient for low-grade lymphomas, but chemotherapy is necessary in patients with high grade lymphomas. Interferon (IFN)-based antiviral treatment regimens for HCV infection are limited by poor tolerance and suboptimal antiviral response. Recently approved novel direct acting antiviral (DAA) drugs are highly effective and safe. This has opened a new era for the treatment of HCV related B-NHL alone or in conjunction with chemotherapy. Treatment of HCV associated $\mathrm{B}-\mathrm{NHL}$ should be performed in an interdisciplinary approach in close consultation with hematologist and hepatologist. In this review, we summarize data regarding clinical features and epidemiology of B-NHL and discuss novel therapeutic approaches, including DAAs, that may prove to be effective in the treatment of HCV associated lymphomas.

(C) 2015 The Second Affiliated Hospital of Chongqing Medical University. Published by XIA \& HE Publishing Ltd. All rights reserved.
\end{abstract}

\section{Introduction}

Chronic hepatitis $\mathrm{C}$ is a worldwide problem affecting nearly 180 million people. Hepatitis C virus (HCV) infection leads to chronic hepatitis and is a major cause of liver cirrhosis and

Keywords: Hepatitis C; Non-Hodgkin lymphoma; Mixed cryoglobulinemia; Rituximab.

Abbreviations: AVT, antiviral therapy; B-NHL, B-cell Non-Hodgkin lymphoma; $D A A$, direct acting antiviral; DFS, disease free survival; DLBCL, diffuse large $B$ cell lymphoma; $\mathrm{HCV}$, hepatitis $\mathrm{C}$ virus; IFN, interferon; $\mathrm{LPL}$, lymphoplasmacytic lymphoma; MALT, mucosa associated lymphoid tissue; MC, mixed cryoglobulinemia; MZL, marginal zone lymphoma; NHL, Non-Hodgkin lymphoma; NMZL, nodal marginal zone lymphoma; SMZL, splenic marginal zone lymphoma; SVR, sustained virologic response; WM, Waldenström's macroglobulinemia.

Received: 06 April 2015; Revised: 16 May 2015; Accepted: 18 May 2015

DOI: $10.14218 /$ JCTH.2015.00011.

*Correspondence to: Gagan K Sood, Department of Surgery, St. Luke's Center for Liver disease, Baylor College of Medicine, 6620 Main Street, Houston, Texas 77030 USA. Tel: +1-832-355-1400, Fax: +1-713-610-2479, E-mail: gksood@bcm.edu hepatocellular carcinoma. ${ }^{1} \mathrm{HCV}$ is also a lymphotropic virus that triggers $\mathrm{B}$-cells and promotes favorable conditions for B lymphocyte proliferation. As a consequence, several lymphoproliferative disorders have been associated with the virus, including mixed cryoglobulinemia (MC) and B-cell non-Hodgkin lymphoma (B-NHL). ${ }^{2,3}$ Recently, many experimental studies have increased our understanding of the molecular mechanisms of HCV-mediated B-cell proliferation and transformation to $\mathrm{NHL} .{ }^{4} \mathrm{HCV}$ eradication with antiviral therapy (AVT) achieves complete regression of a subset of indolent lymphomas. ${ }^{5}$ Immune-chemotherapy followed by AVT is the mainstay of treatment for aggressive lymphomas. Recently approved direct acting antiviral (DAA) agents have significantly changed the treatment of HCV infection. ${ }^{6}$ This raises the hope that high sustained virologic response (SVR) rates achieved with these DAAs will significantly improve the outcome of HCV associated B-NHL.

HCV infection, mixed cryoglobulinemia (MC), and B-NHL

The initial finding that lead to extensive investigation of association between $\mathrm{HCV}$ and $\mathrm{B}-\mathrm{NHL}$ was high prevalence of $\mathrm{HCV}$ infection in patients with type II MC. ${ }^{7}$ Type II MC is characterized by a combination of monoclonal and polyclonal immunoglobulins, with monoclonal component directed against immunoglobulin $\mathrm{G}$ ( $\mathrm{IgG})$. The production of IgG is sustained by the clonal expansion of B-cells. Overt symptoms of cryoglobulinemic vasculitis develop in only approximately $5 \%$ of chronic HCV infection cases, but circulating mixed cryoglobulin complexes are much more common and detected in $40-50 \%$ of chronic HCV-infected patients. ${ }^{8}$ Although clinically benign, MC is a lymphoproliferative disorder that predisposes patients to $\mathrm{B}-\mathrm{NHL}$ in about $5-10 \%$ of cases. ${ }^{9}$ The overall risk of $\mathrm{NHL}$ in patients with $\mathrm{MC}$ is about 35 times higher than that in the general population. ${ }^{10}$ The risk of lymphoma decreases after viral eradication with AVT. In one recent study, clearance of HCV RNA was achieved in nearly $50 \%$ of patients with MC. HCV RNA clearance led to persistent resolution or improvement of symptoms related to MC. No case of lymphoma was observed during a long followup period, ranging from 35-124 months. ${ }^{11}$ Since HCV infects about 180 million individuals worldwide; the number of patients at risk for $\mathrm{MC}$ and its complications is substantial. HCV-MC patients are at higher risk for developing B-NHL and should be considered for AVT even at an early stage of liver disease. 
Tasleem S. et al: HCV and B-NHL

\section{Epidemiology}

Several epidemiological studies have been performed in the last 20 years to investigate the link between HCV and B-NHL. Early studies based on relatively low case numbers revealed a high risk of B-NHL in HCV positive patients, especially from geographical regions with high HCV infection prevalence; ${ }^{12}$ while studies from areas with low prevalence did not show any significant association. ${ }^{13}$

The link between HCV and B-NHL has been strengthened by large epidemiological studies and meta-analyses published in recent years. Gisbert et al. performed a systematic review of studies evaluating the prevalence of HCV infection in B-NHL. ${ }^{14}$ In total, 48 studies (5,542 patients) were identified. Mean HCV infection prevalence in this study was $13 \%$. In 10 case-control studies in which the control group was comprised of healthy donors, HCV prevalence in B-NHL was $17 \%$ compared to $1.5 \%$ in healthy controls (odds ratio $(O R)=10.8$ ). Therefore, it was concluded that HCV prevalence in patients with $\mathrm{B}-\mathrm{NHL}$ is higher than the general population, suggesting a role for HCV in the etiology of B-NHL. Subsequently, in 2006, a meta-analysis of 15 case-control studies on the association between HCV infection and NHL demonstrated a pooled relative risk of lymphoma of 2.5 (95\% confidence interval (CI), 2.1-3.1) among HCV-positive subjects. ${ }^{15}$

The International Lymphoma Epidemiology Consortium (InterLymph) study reported pooled results of HCV related $\mathrm{B}-\mathrm{NHL}$ from a large international multicenter data source. The study included 11,053 participants, 4,784 cases, and 6,269 controls from seven case-control studies conducted in the United States, Europe, and Australia with information on HCV infection. HCV infection was detected in $172 \mathrm{NHL}$ cases $(3.6 \%)$ and in $169(2.7 \%)$ controls (OR=1.8; CI, 1.4-2.3). ${ }^{16}$

Overall, large epidemiologic studies and meta-analyses have shown that HCV infection is an important factor in the development of certain types of B-NHL. ${ }^{12,14,15,17,18}$ Local HCV prevalence and genetic and environmental factors may be responsible for the geographically diverging results.

Common features of HCV related B-NHL are long duration of infection (15 years) and frequent involvement of extranodal sites. The B-NHL subtypes associated with HCV vary between different studies. The B-NHL subtype commonly reported in European and Japanese studies were marginal zone lymphoma (MZL), particularly splenic zone lymphoma (SMZL), lymphoplasmacytic lymphoma (LPL), and diffuse large B-cell lymphoma (DLBCL). ${ }^{14,19}$ In contrast, a recent study from the United States reported that the most common HCV related B-NHLs was DLBCL $(62 \%)$, followed by follicular lymphoma $(13 \%)$ and MZL $(11 \%){ }^{20}$

\section{NHL subtypes associated with HCV}

Chronic HCV infection has been associated with both B-cell indolent lymphomas, especially MZL, and aggressive lymphomas, mainly DLBCL. Indolent lymphomas are defined clinically as minimally symptomatic lymphomas that grow and spread slowly. According to the World Health Organization (WHO) classification system, HCV associated lymphomas include the following histologic subtypes:

\section{(a) Marginal zone lymphoma (MZL)}

Marginal zone lymphomas (MZL) is the most common HCV associated B-NHL subtype and accounts for approximately
$12 \%$ of all B-cell lymphomas. ${ }^{21,22}$ It has a very indolent course and is often diagnosed among patients 65 years and or older patients.

MZL is categorized into three different sub-types: (i) Extranodal MZLmarginal zone lymphoma of mucosaassociated lymphoid tissue (MALT) type; (ii) Nodal marginal zone lymphoma (NMZL); and (iii) Splenic marginal zone lymphoma (SMZL). ${ }^{23}$

MALT lymphoma is the most frequent type of $M Z L$, responsible for $8 \%$ of all NHL. Gastric MALT and nongastric MALT are two subtypes of MALT Iymphomas. There is a wellestablished link between Helicobacter pylori (H. pylori) infection and gastric MALT Iymphoma. HCV infection has also been associated with gastric MALT Iymphoma, ${ }^{24}$ but HCV infection was more often associated with nongastric lymphoma. ${ }^{25} \mathrm{An}$ Italian study showed HCV infection in 60 of 172 (35\%) patients with nongastric MALT Iymphoma. ${ }^{21}$ The most frequent nongastric sites of MALT lymphoma were the skin $(35 \%)$, salivary glands $(25 \%)$, and orbit $(15 \%) .{ }^{21}$ Other studies have also found a link between HCV infection and salivary gland, orbit, and skin MALT Iymphoma. 4,26,27 HCVpositive nongastric MALT lymphomas have an indolent course similar to HCV-negative patients. ${ }^{26}$

The second type of MZL is Nodal Marginal cell Lymohoma (NMZL) also called monocytoid B-cell lymphoma. NMZL is characterized by exclusive primary lymph node localization in absence of prior or concurrent extranodal site involvement. Primary NMZL is a rare disease, accounting for nearly $2 \%$ of lymphoid neoplasms, and is frequently associated with HCV infections. ${ }^{26,28,29}$ In a large series of NMZL reported from Italy, HCV serology was positive in 9 out of 38 patients $(24 \%))^{21}$

The third type of MZL is splenic marginal zone lymphoma (SMZL). It is a rare indolent lymphoma subtype, which accounts for less than $2 \%$ of all NHL. The clinical course is indolent, but symptomatic splenomegaly is the presenting feature in some patients. In a large series of splenic MZL, HCV serology was positive in 49 out of 255 available patients $(19 \%) .{ }^{30}$ Among 56 patients tested for HCV-RNA, $25(45 \%)$ were positive. Cryoglobulins were detected in 13 out of 130 patients tested $(10 \%)$. SMZL was reported to be associated with MC; few studies reported detectable type-II MC in all patients with SMZL. ${ }^{31}$ This observation suggested that HCV associated SMZL with MC may be a separate clinical entity.

\section{(b) Lymphoplasmacytic lymphoma (LPL)}

$\mathrm{LPL}$ is a rare type of $\mathrm{HCV}$ related $\mathrm{B}$-cell NHL. It is composed of a mixture of malignant clonal lymphocytes, plasmacytoid lymphocytes, and plasma cells. It usually involves bone marrow and sometimes the lymph node and spleen. In some patients, LPL is associated with Waldenström's macroglobulinemia (WM). ${ }^{32}$ Patients typically present at an advanced age, and substantial proportions are asymptomatic at diagnosis.

\section{(c) Diffuse large B-cell lymphoma (DLBCL)}

In Western countries, DLBCL is the most common lymphoma subtype associated with HCV infection. ${ }^{33}$ DLBCL frequently develops from low-grade lymphomas. In the ANRS HC-13 lympho-C study, 16/45 (36\%) were transformed from underlying indolent lymphomas, mainly MZL. ${ }^{34}$ The clinical 
presentation of HCV-associated DLBCL has been consistently reported to differ from HCV negative lymphoma. ${ }^{27,35} \mathrm{DLBCL}$ is characterized by aggressive clinical behavior, and $\mathrm{HCV}$ related DLBCL has peculiar characteristics. HCV-positive DLBCL patients are usually older and are more likely to have spleen/liver or extranodal involvement and elevated lactate dehydrogenase. ${ }^{35,36}$

\section{Pathogenesis}

$\mathrm{HCV}$ is a positive, single-strand RNA virus without a DNA intermediate in its replicative cycle; and integration of $\mathrm{HCV}$ nucleic-acid sequences into the host genome seems unlikely. ${ }^{2}$ Therefore, HCV is not considered an oncogenic virus. It has been suggested that HCV infection exerts a chronic antigenic stimulus on the immune system, very similar to $H$. pylori in gastric MALT lymphoma.

According to a multistep theory of lymphomagenesis, the first step in antigenic stimulation is replication of $\mathrm{HCV}$, which leads to proliferation of B-lymphocytes and subsequent development of MC. This causes generation of low grade $\mathrm{NHL}$, and this occurs in some patients as a second step. The pathologic process can be reversed at this stage with eradication of the virus. In the final step, due to subsequent accumulation of additional mutations and genetic alterations, antigen dependency is lost and viral elimination by itself is insufficient for the treatment of HCV associated high grade NHL. ${ }^{33,37}$ Biological processes and molecular mechanisms involved in development of $\mathrm{NHL}$ have been investigated $^{4,38}$ but are beyond the scope of this review.

\section{Antiviral therapy for HCV associated B-NHL}

AVT is effective in low-grade lymphomas. Numerous studies have reported regression of lymphoma after AVT, but these studies were limited by their retrospective design, small number of patients, and variable AVT protocols. ${ }^{39-45}$ Early studies used IFN- $\alpha$, but later studies used pegylated IFN with and without ribavirin. These studies are summarized in Table 1; studies containing single case reports or a small number of patients were excluded. $5,27,39-42,44,46$

Recently, Arcaini et al. reported updated results from the Italian lymphoma consortium. ${ }^{5}$ They followed $704 \mathrm{HCV}$ positive patients with indolent B-NHL between 1993 and 2009 at 39 centers. Among these, 100 patients received as the first line of treatment AVT with either IFN- $\alpha$ or pegylated IFN alone or with ribavirin. Virological and hematological remission was achieved in a large number of patients. HCV RNA clearance was achieved in $80 \%$ patients, $44 \%$ patients achieved complete remission, and $33 \%$ achieved partial remission of B-NHL. ${ }^{5}$ The use of AVT at any time during the life of these patients seemed to be associated with improved outcome and, based on this, investigators recommended that AVT must be considered as a first line approach for patients with indolent lymphoma. The high rate of HCV clearance achieved in this study was probably related to a preponderance of HCV genotype 2 infection (55\%), which is more responsive to AVT.

Michot et al. reported the effect of AVT on HCV associated $\mathrm{B}-\mathrm{NHL}$ in a multicenter ANRS HC-13 Lympho-C study. This French study enrolled $116 \mathrm{HCV}$-positive patients with B-NHL between 2006 and 2012. Fourteen patients with MZL were given AVT only as first line of therapy. Of those, 11 achieved SVR and hematological remission. Nonresponders to AVT

Table 1. Studies of antiviral treatment in patients with HCV-associated lymphoma

\begin{tabular}{|c|c|c|c|c|c|}
\hline & $\mathrm{N}^{\circ}$ Pts $*$ & $\begin{array}{l}\text { Antiviral } \\
\text { treatment }\end{array}$ & Diagnosis & Virologic response & NHL response \\
\hline $\begin{array}{l}\text { Hermine et al., } \\
2002^{39}\end{array}$ & 9 & IFN $\alpha$ & SLVL & 7 & $7 \mathrm{CR}$ \\
\hline $\begin{array}{l}\text { Kelaidi et al., } \\
2004^{41}\end{array}$ & 8 & $\mathrm{IFN} \alpha+\mathrm{RBV}$ & $\begin{array}{l}\text { SMZL }(n=4) \\
\text { MZL/MALT }(n=4)\end{array}$ & 5 SVR, 2 NSVR & $5 \mathrm{CR}$ \\
\hline $\begin{array}{l}\text { Tursi et al., } \\
2002^{42}\end{array}$ & 16 & IFN $\alpha+$ RBV & MZL/MALT & 11 & $16 \mathrm{CR}$ \\
\hline $\begin{array}{l}\text { Saadoun et al., } \\
2005^{43}\end{array}$ & 18 & IFN $\alpha$ IFN $\alpha+$ RBV & SLVL & $14 \mathrm{CR}, 4$ NSVR & $14 \mathrm{CR}, 4 \mathrm{PR}$ \\
\hline $\begin{array}{l}\text { Mazzaro et al., } \\
2009^{44}\end{array}$ & 18 & $\begin{array}{l}\text { IFN } \alpha+\text { RBV } \\
\text { PegIFN } \alpha+\text { RBV }\end{array}$ & $\begin{array}{l}\operatorname{SLVL}(n=1) \\
\operatorname{FL}(n=1), \operatorname{LPL}(n=16)\end{array}$ & $\begin{array}{l}3 \text { SVR, } 4 \text { NR, } 1 \text { NSVR } \\
6 \text { SVR, } 2 \text { NR, } 2 \text { NSVR }\end{array}$ & $\begin{array}{l}3 \mathrm{CR}, 2 \mathrm{PR} \\
6 \mathrm{CR}, 2 \mathrm{PR}\end{array}$ \\
\hline $\begin{array}{l}\text { Pellicelli et al., } \\
2011^{45}\end{array}$ & 9 & PegIFN $\alpha+$ RBV & $\begin{array}{l}\text { SMZL }(n=3), \\
\operatorname{MZL}(n=4), \operatorname{FL}(n=2)\end{array}$ & 7 SVR, 2 NSVR & $5 \mathrm{CR}, 2 \mathrm{PR}$ \\
\hline $\begin{array}{l}\text { Vallisa et al., } \\
2005^{40}\end{array}$ & 13 & PegIFN $\alpha+$ RBV & $\begin{array}{l}\operatorname{SMZL}(n=4), \\
\operatorname{MZL} / \operatorname{MALT}(n=4), \\
\operatorname{FL}(n=1), \operatorname{LPL}(n=4)\end{array}$ & 7 SVR, 1 NSVR & $7 \mathrm{CR}, 2 \mathrm{PR}$ \\
\hline $\begin{array}{l}\text { Arcaini et al., } \\
2014^{5}\end{array}$ & 100 & $\begin{array}{l}\text { IFN } \alpha+\text { RBV } \\
\text { PegIFN } \alpha+\text { RBV }\end{array}$ & $\begin{array}{l}\operatorname{SMZL}(n=36) \\
\operatorname{MZL} / \operatorname{MALT}(n=29), \\
\text { FL }(n=12), \operatorname{LPL}(n=10)\end{array}$ & 80 SVR & $44 \mathrm{CR}, 33 \mathrm{PR}$ \\
\hline $\begin{array}{l}\text { Michot, JM } \\
\text { et al., } 2015^{67}\end{array}$ & 116 & $\begin{array}{l}\text { IFN } \alpha+\text { RBV } \\
\text { PegIFN } \alpha+\text { RBV }\end{array}$ & $\begin{array}{l}\text { MZL }(n=45) \\
\text { (AVT only first line } N=14)\end{array}$ & 11 SVR, 3 NSVR & $8 \mathrm{CR}, 3 \mathrm{PR}$ \\
\hline
\end{tabular}

MALT, mucosa associated lymphoid tissue; MZL, marginal zone lymphoma; SMZL, splenic marginal zone lymphoma; AVT, antiviral therapy; IFN, interferon; CR, complete response; PR, partial response; SVR, sustained virologic response; NSVR, nonsustained virologic response; n.a, not available. 
were treated with a combination of AVT and rituximab. ${ }^{46}$ Patients who received AVT at the time of diagnosis of NHL or during follow-up had significantly better overall survival.

Recently, DAA has significantly increased the SVR in patients with chronic HCV. ${ }^{6,47}$ A few highly encouraging reports demonstrated lymphoma regression after HCV clearance with DAAs. Rossotti et al. reported a rapid virologic and hematologic response with an all-oral, IFN-free regimen, based on the combination of a NS3/NS4A inhibitor (faldaprevir) and a non-nucleoside NS5B inhibitor (deleobuvir) in a patient with HCV associated SMZL. The viral load decreased to undetectable levels within 4 weeks of treatment, and hematologic response was achieved within 8 weeks. ${ }^{48}$ This is a typical feature in the DAA era, where virologic response is significantly enhanced compared to the classic IFN- and ribavirin-based treatment. 6,49 In another report, Sultanik et al. showed complete regression of MZL after 12 weeks of therapy with sofosobuvir and ribavirin. ${ }^{50}$

$A$ regimen including DAAs may be considered when treating HCV-related extra-hepatic disease. Until 2011, the combination of pegylated IFN- $\alpha$ and ribavirin for 24 or 48 weeks was the approved treatment for chronic hepatitis $\mathrm{C}$. With this regimen, patients infected with HCV genotype 1 had SVR rates of approximately $40 \%$ in North America and $50 \%$ in Western Europe. Higher SVR rates were achieved in patients infected with HCV genotypes 2 and 3. In 2011, telaprevir and boceprevir were licensed for use in HCV genotype 1 infection. These two drugs were first-wave, first-generation DAAs. However, the side effect profiles of these triple combination therapies were not favorable and are no longer used in patients infected with $\mathrm{HCV}^{51}$ Currently, in addition to pegylated IFN- $\alpha$ and ribavirin, three new HCV DAAs are available in Europe and the United States for use as part of combination therapies for HCV infection. Sofosbuvir (nucleotide analogue inhibitor of HCV RNA-dependent RNA polymerase), ledispavir, and daclatasvir (NS5A inhibitors ) have been approved in Europe. ${ }^{6,47}$ In the United States Sofosobuvir alone or in combination with ledispavir is available. In addition, high SVR rates have been achieved by combining paritaprevir with ritonavir, ombitasvir, and dasabuvir. These combinations of DAA are highly effective, safe, well-tolerated, and with limited drug interactions. ${ }^{52-57}$ In patients with HCV related indolent $\mathrm{B}-\mathrm{NHL}$, the first line of therapy may be offered, using combination of these highly active antiviral agents. These regimens, however, need to be studied in clinical trials, for determination of optimal dose and duration for treatment of $\mathrm{HCV}$ associated $\mathrm{B}-\mathrm{NHL}$.

\section{Management of DLBCL associated with HCV}

For the management of HCV-associated DLBCL, anthracycline-based chemotherapy [cyclophosphamide, hydroxydaunorubicin, vincristine, and prednisolone (CHOP)] combined with rituximab is the standard of care. AVT to eradicate HCV is the logical step after successful chemotherapy. The use of sequential immunochemotherapy followed by AVT has promising results in some studies. ${ }^{58,59}$ La Mura et al. reported improved disease free survival (DFS) and clinical outcome with AVT after immunochemotherapy. ${ }^{60}$ In a French multicenter ANRS Lympho-C study, most DLBCL patients received front-line immunochemotherapy with a standard anthracycline regimen (R-CHOP). Seventeen of 45 (38\%) with DLBCL also received antiviral treatment. Patients who received AVT at the time of diagnosis of NHL or during follow-up had significantly better OS $(p=0.029)$ and PFS $(p=0.049)$ than those who did not receive antiviral treatment. ${ }^{34}$

The addition of rituximab to chemotherapy is considered the greatest advance in the treatment of B-NHL. Addition of rituximab enhances viral replication, but the probability of severe hepatic complications remain variable in different studies. ${ }^{5,61-63}$ Ennishi et al. reported hepatotoxicity was more likely to occur if pretreatment aminotransferase levels were high. ${ }^{64}$ Besson et al. reported hepatotoxicity increased with each cycle of chemotherapy and proposed that this may be related to increased viral replication or immune reactivation after stopping chemotherapy. ${ }^{61} \mathrm{~A}$ recent study from Egypt reported 53/200 (26\%) patients with HCV-B-NHL on rituximab experienced significant hepatotoxicity compared to those on rituximab free regimens, $11 / 80(14 \%)$. There was no information about HCV RNA replication in this study. ${ }^{65}$ Zaki et al. reported severe hepatotoxicity (aspartate aminotransferase (AST)/alanine aminotransferase (ALT) $>5$ upper limit of normal (ULN)) in $28 \%$ and vs. $14 \%$ of patients treated with R-CHOP and compared to rituximab free regimen, respectively. ${ }^{66}$ Hepatic toxicity led to the modification and the discontinuation of immune-chemotherapy in nearly $25 \%$ of patients, resulting in progression of lymphoma. They also demonstrated increased HCV RNA replication during chemotherapy. ${ }^{66}$ In another study, Arcaini et al. also reported significant hepatotoxicity in HCV-positive DLBCL treated by rituximab but found no correlation with HCV RNA levels. ${ }^{5}$ Monitoring of serum HCV-RNA levels and transaminases may be helpful to understand the cause of liver dysfunction in patients receiving chemotherapy. Several issues, like clinical management of patients with advanced liver disease or baseline transaminases elevation, and risk of HCV replication during immunotherapy, remain unclear. Further studies will be necessary to investigate fully the relationship between changes in HCV viral load and liver function during chemotherapy in order to prevent unnecessary dose modifications or stopping chemotherapy due to hepatotoxicity.

In earlier studies, antiviral prophylaxis was not protective against HCV replication in patients receiving chemotherapy. However, these prior studies used IFN-based regimens, which were less efficacious and had higher hematological side effects. With the availability of the new potent DAAs sofosobuvir, ledispavir, and daclatasvir, new approaches for HCV eradication, before or concomitant with chemotherapy, should be evaluated in controlled clinical trials. Newer antiviral agents are well-tolerated with very high efficacy, have a strong safety profile, ${ }^{6,54}$ and may be used in conjunction with chemotherapeutic agents. HCV eradication also reduces the risk of lymphoma relapse. In one study, none of the patients with eradicated HCV infection had relapse, while one-third of cases that did not respond to antiviral treatment showed relapse. ${ }^{60}$

Well-designed multicenter studies will be necessary to determine whether early detection and prevention of HCV replication will provide improved disease management for HCV-infected patients receiving immunochemotherapy.

\section{Conclusions}

The spectrum of HCV infection include hematological manifestations such as MC and B-NHL. The most common B-NHL subtypes associated with HCV infection are MZL and DLBCL. Antiviral treatment achieves virological and hematological 
remission in $\mathrm{HCV}$ associated indolent lymphoma. More aggressive lymphoma requires combination of AVT and chemotherapy. New generation HCV antiviral drugs are safe and highly efficacious. Regimens including DAAs appear promising and should be investigated in clinical trials for treatment of HCV-related extrahepatic disease. HCV associated B-NHL should be treated in close association with hepatologist and hematologist.

\section{Conflict of interest}

None

\section{Author contributions}

Review of literature and drafting article (ST), drafting the article and revising the article for important intellectual content (GKS).

\section{References}

[1] Zuckerman E, Zuckerman T, Levine AM, Douer D, Gutekunst K, Mizokami M, et al. Hepatitis C virus infection in patients with B-cell non-hodgkin lymphoma. Ann Intern Med 1997;127:423-428. doi:10.7326/0003-4819-1276-199709150-00002.

[2] Paydas S, Kilic B, Yavuz S, Disel U, Tanriverdi K, Sahin B, et al. Anti-HCV and HCV-RNA prevalence and clinical correlations in cases with non-hodgkin's lymphoma. Am J Hematol 2003;74:89-93. doi:10.1002/ajh.10386.

[3] Paydas S. Hepatitis C virus and lymphoma. Crit Rev Oncol Hematol 2015;93: 246-256. doi:S1040-8428(14)00168-1.

[4] Peveling-Oberhag J, Arcaini L, Hansmann ML, Zeuzem S. Hepatitis C-associated B-cell non-hodgkin lymphomas. epidemiology, molecular signature and clinical management. J Hepatol 2013;59:169-177. doi:10.1016/j.jhep.2013.03.018.

[5] Arcaini L, Vallisa D, Rattotti S, Ferretti VV, Ferreri AJ, Bernuzzi $P$, et al. Antiviral treatment in patients with indolent B-cell lymphomas associated with HCV infection: A study of the fondazione italiana linfomi. Ann Oncol 2014;25: 1404-1410. doi:10.1093/annonc/mdu166.

[6] Pawlotsky JM. New hepatitis C virus (HCV) drugs and the hope for a cure: Concepts in anti-HCV drug development. Semin Liver Dis 2014;34:22-29. doi:10.1055/s-0034-1371007.

[7] Agnello V, Chung RT, Kaplan LM. A role for hepatitis C virus infection in type II cryoglobulinemia. N Engl J Med 1992;327:1490-1495. doi:10. 1056/NEJM199211193272104.

[8] Cacoub P, Maisonobe T, Thibault V, Gatel A, Servan J, Musset L, et al. Systemic vasculitis in patients with hepatitis C. J Rheumatol 2001;28:109-118.

[9] Ferri C, Sebastiani M, Giuggioli D, Cazzato M, Longombardo G, Antonelli A, et al. Mixed cryoglobulinemia: Demographic, clinical, and serologic features and survival in 231 patients. Semin Arthritis Rheum 2004;33:355-374. doi: S0049017203001793.

[10] Monti G, Pioltelli P, Saccardo F, Campanini M, Candela M, Cavallero G, et al. Incidence and characteristics of non-hodgkin lymphomas in a multicenter case file of patients with hepatitis C virus-related symptomatic mixed cryoglobulinemias. Arch Intern Med 2005;165:101-105.

[11] Gragnani L, Fognani E, Piluso A, Boldrini B, Urraro T, Fabbrizzi A, et al . Longterm effect of $\mathrm{HCV}$ eradication in patients with mixed cryoglobulinemia: A prospective, controlled, open-label, cohort study. Hepatology 2015;61: 1145-1153. doi:10.1002/hep.27623.

[12] Talamini R, Montella M, Crovatto M, Dal Maso L, Crispo A, Negri E, et al. Nonhodgkin's lymphoma and hepatitis $C$ virus: A case-control study from northern and southern italy. Int J Cancer 2004;110:380-385. doi:10.1002/ijc.20137.

[13] Collier JD, Zanke B, Moore M, Kessler G, Krajden M, Shepherd F, et al. No association between hepatitis $C$ and B-cell lymphoma. Hepatology 1999;29: 1259-1261. doi:S0270913999001913.

[14] Gisbert JP, Garcia-Buey L, Arranz R, Blas C, Pinilla I, Khorrami S, et al. The prevalence of hepatitis $C$ virus infection in patients with non-hodgkin's lymphoma. Eur J Gastroenterol Hepatol 2004;16:135-138. doi:00042737200402000-00003.

[15] Dal Maso L, Franceschi S. Hepatitis C virus and risk of lymphoma and other lymphoid neoplasms: A meta-analysis of epidemiologic studies. Cancer Epidemiol Biomarkers Prev 2006;15:2078-2085. doi:10.1158/1055-9965. EPI-06-0308.

[16] de Sanjose S, Benavente Y, Vajdic CM, Engels EA, Morton LM, Bracci PM, et al. Hepatitis $C$ and non-hodgkin lymphoma among 4784 cases and 6269 con- trols from the international lymphoma epidemiology consortium. Clin Gastroenterol Hepatol 2008;6:451-458. doi:10.1016/j.cgh.2008.02.011.

[17] Guadagnino V, Stroffolini T, Rapicetta M, Costantino A, Kondili LA, Menniti-

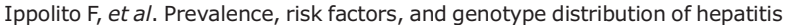
$C$ virus infection in the general population: A community-based survey in southern italy. Hepatology 1997;26:1006-1011. doi:S0270913997004527.

[18] Matsuo K, Kusano A, Sugumar A, Nakamura S, Tajima K, Mueller NE. Effect of hepatitis $C$ virus infection on the risk of non-hodgkin's lymphoma: A meta-analysis of epidemiological studies. Cancer Sci 2004;95:745-752. doi: 10.1111/j.1349-7006.2004.tb03256.x.

[19] Arcaini L, Paulli M, Boveri E, Vallisa D, Bernuzzi P, Orlandi E, et al. Splenic and nodal marginal zone lymphomas are indolent disorders at high hepatitis $C$ virus seroprevalence with distinct presenting features but similar morphologic and phenotypic profiles. Cancer 2004;100:107-115. doi:10.1002/cncr. 11893.

[20] Torres HA, Mahale P. Most patients with HCV-associated lymphoma present with mild liver disease: A call to revise antiviral treatment prioritization. Liver Int 2015;35(6):1661-1664. doi:10.1111/liv.12825.

[21] Arcaini L, Burcheri S, Rossi A, Paulli M, Bruno R, Passamonti F, et al. Prevalence of HCV infection in nongastric marginal zone B-cell lymphoma of MALT. Ann Oncol 2007;18:346-350. doi:10.1093/annonc/mdl388.

[22] Arcaini L, Merli M, Volpetti S, Rattotti S, Gotti M, Zaja F. Indolent B-cell lymphomas associated with $\mathrm{HCV}$ infection: Clinical and virological features and role of antiviral therapy. Clin Dev Immunol 2012;2012:638185. doi: $10.1155 / 2012 / 638185$

[23] Sulyok M, Makara M, Ujhelyi E, Valyi-Nagy I. Non-hodgkin lymphoma and hepatitis C: Where we are and what next? Pathol Oncol Res 2015;21:1-7. doi: $10.1007 / \mathrm{s} 12253-014-9845-z$.

[24] Luppi M, Grazia Ferrari M, Bonaccorsi G, Longo G, Narni F, Barozzi P, et al. Hepatitis $C$ virus infection in subsets of neoplastic lymphoproliferations not associated with cryoglobulinemia. Leukemia 1996;10:351-355.

[25] De Vita S, De Re V, Sansonno D, Sorrentino D, Corte RL, Pivetta B, et al. Gastric mucosa as an additional extrahepatic localization of hepatitis C virus: Viral detection in gastric low-grade lymphoma associated with autoimmune disease and in chronic gastritis. Hepatology 2000;31:182-189. doi: S0270913900783480.

[26] Arcaini L, Burcheri S, Rossi A, Paulli M, Bruno R, Passamonti F, et al. Prevalence of $\mathrm{HCV}$ infection in nongastric marginal zone B-cell lymphoma of MALT. Ann Oncol 2007;18:346-350. doi:10.1093/annonc/mdl388.

[27] Pellicelli AM, Marignani M, Zoli V, Romano M, Morrone A, Nosotti L, et al. Hepatitis $C$ virus-related B cell subtypes in non hodgkin's lymphoma. World J Hepatol 2011;3:278-284. doi:10.4254/wjh.v3.i11.278.

[28] Arcaini L, Paulli M, Boveri E, Vallisa D, Bernuzzi P, Orlandi E, et al. Splenic and nodal marginal zone lymphomas are indolent disorders at high hepatitis $C$ virus seroprevalence with distinct presenting features but similar morphologic and phenotypic profiles. Cancer 2004;100:107-115. doi:10.1002/cncr. 11893.

[29] Ferreri AJ, Viale E, Guidoboni M, Resti AG, De Conciliis C, Politi L, et al. Clinical implications of hepatitis C virus infection in MALT-type lymphoma of the ocular adnexa. Ann Oncol 2006;17:769-772. doi:10.1093/annonc/mdl027.

[30] Arcaini L, Lazzarino M, Colombo N, Burcheri S, Boveri E, Paulli M, et al. Splenic marginal zone lymphoma: A prognostic model for clinical use. Blood 2006;107:4643-4649.

[31] Saadoun D, Suarez F, Lefrere F, Valensi F, Mariette X, Aouba A, et al. Splenic lymphoma with villous lymphocytes, associated with type II cryoglobulinemia and HCV infection: A new entity? Blood 2005;105:74-76. doi:10. 1182/blood-2004-05-1711.

[32] Arcaini L, Varettoni M, Boveri E, Orlandi E, Rattotti S, Zibellini S, et al. Distinctive clinical and histological features of waldenstrom's macroglobulinemia and splenic marginal zone Iymphoma. Clin Lymphoma Myeloma Leuk 2011;11:103-105. doi:10.3816/CLML.2011.n.020.

[33] de Re V, Caggiari L, Simula MP, de Vita S, Sansonno D, Dolcetti R. B-cell lymphomas associated with HCV infection. Gastroenterology 2007;132: 1205-1207. doi:S0016-5085(07)00356-3.

[34] Michot JM, Canioni D, Driss H, Alric L, Cacoub P, Suarez F, et al. Antiviral therapy is associated with a better survival in patients with hepatitis $C$ virus and B-cell non-hodgkin lymphomas, ANRS HC-13 lympho-C study. Am J Hematol 2015;90:197-203. doi:10.1002/ajh.23889.

[35] Visco C, Finotto S. Hepatitis C virus and diffuse large B-cell lymphoma: Pathogenesis, behavior and treatment. World J Gastroenterol 2014;20: 11054-11061. doi:10.3748/wjg.v20.i32.11054.

[36] Pellicelli AM, Marignani M, Zoli V, Romano M, Morrone A, Nosotti L, et al. Hepatitis $C$ virus-related $B$ cell subtypes in non hodgkin's lymphoma. World J Hepatol 2011;3:278-284. doi:10.4254/wjh.v3.i11.278.

[37] De Re V, De Vita S, Marzotto A, Gloghini A, Pivetta B, Gasparotto D, et al. Pre-malignant and malignant lymphoproliferations in an HCV-infected type II mixed cryoglobulinemic patient are sequential phases of an antigen-driven pathological process. Int J Cancer 2000;87:211-216. doi:10.1002/10970215(20000715)87:2<211::AID-IJC9>3.0.CO;2-8. 
[38] Zignego AL, Gragnani L, Piluso A, Sebastiani M, Giuggioli D, Fallahi $P$, et al. Virus-driven autoimmunity and lymphoproliferation: The example of $\mathrm{HCV}$ infection. Expert Rev Clin Immunol 2015;11:15-31. doi:10.1586/ 1744666X.2015.997214

[39] Hermine O, Lefrere F, Bronowicki JP, Mariette X, Jondeau K, Eclache-Saudreau $V$, et al. Regression of splenic lymphoma with villous lymphocytes after treatment of hepatitis C virus infection. N Engl J Med 2002;347: 89-94. doi:10.1056/NEJMoa013376.

[40] Vallisa D, Bernuzzi P, Arcaini L, Sacchi S, Callea V, Marasca R, et al. Role of anti-hepatitis C virus (HCV) treatment in HCV-related, low-grade, B-cell, non-hodgkin's lymphoma: A multicenter italian experience. J Clin Onco 2005;23:468-473. doi:10.1200/JCO.2005.06.008.

[41] Kelaidi C, Rollot F, Park S, Tulliez M, Christoforov B, Calmus Y, et al. Response to antiviral treatment in hepatitis $C$ virus-associated marginal zone lymphomas. Leukemia 2004;18:1711-1716. doi:10.1038/sj.leu.2403443.

[42] Tursi A, Brandimarte G, Torello M. Disappearance of gastric mucosaassociated lymphoid tissue in hepatitis $\mathrm{C}$ virus-positive patients after anti-hepatitis C virus therapy. J Clin Gastroenterol 2004;38:360-363. doi: 00004836-200404000-00011.

[43] Saadoun D, Resche Rigon M, Pol S, Thibault V, Blanc F, Pialoux G, et al. PegIFNalpha/ribavirin/protease inhibitor combination in severe hepatitis $C$ virus-associated mixed cryoglobulinemia vasculitis. J Hepatol 2015;62: 24-30. doi:10.1016/j.jhep.2014.08.015.

[44] Mazzaro C, De Re V, Spina M, Dal Maso L, Festini G, Comar C, et al. Pegylated-interferon plus ribavirin for HCV-positive indolent non-hodgkin lymphomas. Br J Haematol 2009;145:255-257. doi:10.1111/j.1365-2141. 2008.07565.x.

[45] Pellicelli AM, Zoli V. Role of ribavirin in hepatitis flare in HCV-infected patients with B cell non hodgkin's lymphoma treated with rituximab-containing regimens. Dig Liver Dis 2011;43:501-502. doi:10.1016/j.dld.2010.12.018.

[46] Michot JM, Canioni D, Driss H, Alric L, Cacoub P, Suarez F, et al. Antiviral therapy is associated with a better survival in patients with hepatitis $C$ virus and B-cell non-hodgkin lymphomas, ANRS HC-13 lympho-C study. Am J Hematol 2015;90:197-203. doi:10.1002/ajh.23889.

[47] Rai $D$, Wang $L$, Jiang $X$, Zhan $P$, Jia $H$, De Clercq $E$, et al. The changing face of hepatitis C: Recent advances on HCV inhibitors targeting NS5A. Curr Med Chem 2015, Feb 9.

[48] Rossotti R, Travi G, Pazzi A, Baiguera C, Morra E, Puoti M. Rapid clearance of $\mathrm{HCV}$-related splenic marginal zone lymphoma under an interferon-free, NS3/NS4A inhibitor-based treatment. A case report. J Hepatol 2015;62: 234-237. doi:10.1016/j.jhep.2014.09.031.

[49] Miller MH, Agarwal K, Austin A, Brown A, Barclay ST, Dundas P, et al. Review article: 2014 UK consensus guidelines - hepatitis $C$ management and directacting anti-viral therapy. Aliment Pharmacol Ther 2014;39:1363-1375. doi: 10.1111/apt.12764.

[50] Sultanik P, Klotz C, Brault P, Pol S, Mallet V. Regression of an HCV-associated disseminated marginal zone lymphoma under IFN-free antiviral treatment. Blood 2015;125:2446-2447. doi:10.1182/blood-2014-12-618652.

[51] Butt AA, Yan P, Shaikh OS, Freiberg MS, Lo Re V 3rd, Justice AC, et al. Virologic response and haematologic toxicity of boceprevir- and telaprevircontaining regimens in actual clinical settings. J Viral Hepat 2014, Dec 18 doi: $10.1111 /$ jvh.12375.

[52] Bourliere M, Bronowicki JP, de Ledinghen V, Hézode C, Zoulim F, Mathurin $P_{r}$ et al. Ledipasvir-sofosbuvir with or without ribavirin to treat patients with HCV genotype 1 infection and cirrhosis non-responsive to previous protease-inhibitor therapy: A randomised, double-blind, phase 2 trial (SIRIUS). Lancet Infect Dis 2015;15:397-404. doi:10.1016/S1473-3099 (15)70050-2.

[53] Lawitz E, Poordad FF, Pang PS, Hyland RH, Ding X, Mo H, et al. Sofosbuvir and ledipasvir fixed-dose combination with and without ribavirin in treatment- naive and previously treated patients with genotype 1 hepatitis $C$ virus infection (LONESTAR): An open-label, randomised, phase 2 trial. Lancet 2014;383:515-523. doi:10.1016/S0140-6736(13)62121-2.

[54] Sulkowski MS, Gardiner DF, Rodriguez-Torres M, Reddy KR, Hassanein T, Jacobson I, et al . Daclatasvir plus sofosbuvir for previously treated or untreated chronic HCV infection. N Engl J Med 2014;370:211-221. doi:10. 1056/NEJMoa1306218.

[55] Kowdley KV, Gordon SC, Reddy KR, Rossaro L, Bernstein DE, Lawitz E, et al. Ledipasvir and sofosbuvir for 8 or 12 weeks for chronic HCV without cirrhosis. N Engl J Med 2014;370:1879-1888. doi:10.1056/NEJMoa1402355.

[56] Gane EJ, Stedman CA, Hyland RH, Ding X, Svarovskaia E, Subramanian GM, et al. Efficacy of nucleotide polymerase inhibitor sofosbuvir plus the NS5A inhibitor ledipasvir or the NS5B non-nucleoside inhibitor GS-9669 against HCV genotype 1 infection. Gastroenterology 2014;146:736-743.e1. doi: 10.1053/j.gastro.2013.11.007.

[57] Keating GM. Sofosbuvir: A review of its use in patients with chronic hepatitis C. Drugs 2014;74:1127-1146. doi:10.1007/s40265-014-0247-z.

[58] Nishikawa H, Tsudo M, Osaki Y. Clinical outcome in diffuse large B-cell lymphoma with hepatitis $C$ virus infection in the rituximab era: A single center experience. Oncol Rep 2012;28:835-840. doi:10.3892/or.2012. 1883.

[59] Chen TT, Chiu CF, Yang TY, Lin CC, Sargeant AM, Yeh SP, et al. Hepatitis C infection is associated with hepatic toxicity but does not compromise the survival of patients with diffuse large B cell lymphoma treated with rituximab-based chemotherapy. Leuk Res 2015;39:151-156. doi:10. 1016/j.leukres.2014.11.015.

[60] La Mura V, De Renzo A, Perna F, D'Agostino D, Masarone M, Romano M, et al. Antiviral therapy after complete response to chemotherapy could be efficacious in HCV-positive non-hodgkin's lymphoma. J Hepatol 2008;49: 557-563. doi:10.1016/j.jhep.2008.06.025.

[61] Besson C, Canioni D, Lepage E, Pol S, Morel P, Lederlin P, et al. Characteristics and outcome of diffuse large B-cell lymphoma in hepatitis $C$ virus-positive patients in LNH 93 and LNH 98 groupe d'etude des lymphomes de l'adulte programs. J Clin Oncol 2006;24:953-960. doi:10.1200/JCO.2005.01. 5016.

[62] Zaky AH, Bakry R, El-sayed MI, Elwanis MA, Nabih O. Impact of treatmentrelated toxicity on outcome of $\mathrm{HCV}$-positive diffuse large B-cell lymphoma in rituximab era. Hematology 2014;19:412-416. doi:10.1179/1607845413Y. 0000000147.

[63] Salah-Eldin MA, Ebrahim MA, El-Sadda W. Clinical outcome of HCV-positive patients with diffuse large B-cell lymphoma treated with rituximab-based chemotherapy. Ann Hematol 2014;93:1903-1911. doi:10.1007/s00277014-2138-5.

[64] Ennishi D, Maeda Y, Niitsu N, Kojima M, Izutsu K, Takizawa J, et al. Hepatic toxicity and prognosis in hepatitis $C$ virus-infected patients with diffuse large B-cell lymphoma treated with rituximab-containing chemotherapy regimens: A japanese multicenter analysis. Blood 2010;116:5119-5125. doi: 10.1182/blood-2010-06-289231.

[65] Salah-Eldin MA, Ebrahim MA, El-Sadda W. Clinical outcome of HCV-positive patients with diffuse large B-cell lymphoma treated with rituximab-based chemotherapy. Ann Hematol 2014;93:1903-1911. doi:10.1007/s00277014-2138-5.

[66] Zaky AH, Bakry R, El-sayed MI, Elwanis MA, Nabih O. Impact of treatmentrelated toxicity on outcome of HCV-positive diffuse large B-cell lymphoma in rituximab era. Hematology 2014;19:412-416. doi:10.1179/1607845413Y. 0000000147.

[67] Michot JM, Canioni D, Driss H, Alric L, Cacoub P, Suarez F, et al. Antiviral therapy is associated with a better survival in patients with hepatitis $C$ virus and B-cell non-hodgkin lymphomas, ANRS HC-13 lympho-C study. Am J Hematol 2015;90:197-203. doi:10.1002/ajh.23889. 